\title{
Physiological Responses of Mithipagal Genotypes (Momordica charantia var. muricata L.) under Sodic Condition
}

\author{
S. Priyadharshini, K. Kumanan* and A. Sabir Ahamed \\ Department of Vegetable Science, Horticultural College and Research Institute for Women, \\ Tamil Nadu Agricultural University, Tiruchirappalli \\ *Corresponding author
}

K e y w o r d s
$\begin{aligned} & \text { Antioxidant } \\ & \text { enzyme, Sodicity, } \\ & \text { Chlorophyll } \\ & \text { content, Proline } \\ & \text { content, Mithipagal }\end{aligned}$
Article Info
$\begin{aligned} & \text { Accepted: } \\ & \text { 26 May } 2020 \\ & \text { Available Online: } \\ & \text { 10 June } 2020\end{aligned}$

\section{A B S T R A C T}

Sodicity is a major abiotic stress reducing the yield of a wide variety of crops all over the world. In order to investigate the antioxidant enzymes activity of 30 mithipagal genotypes in relation to the sodicity tolerance study was taken up at Horticultural College and Research Institute for Women, Tiruchirappalli during Kharif season of 2017. When plants are exposed to severe salt stress, suffer from membrane destabilization and general nutrient imbalances that alter their physiology and defence mechanisms. The antioxidant enzyme system of plants plays an important role in the scavenging of Reactive Oxygen Species (ROS) that accumulate during stress and is the first line of defence to counter the deleterious stress effects. Proline content significantly increased in salt-tolerant mithipagal genotypes and the highest proline content was obtained from MCM-19 (Naduvakurichi local) under sodic soil condition. Catalase and peroxidase activities significantly decreased in salt-sensitive genotype whereas significantly increased in salt-tolerant genotypes. The salt-tolerant genotype MCM-19 (Naduvakurichi local) maintained higher levels of chlorophyll and proline contents as well as catalase and peroxidase activities under sodic soil condition followed by MCM-22 (Puthiyamputhur local) and MCM-21 (Arupukottai local), thus, this might be the underlying mechanism for salt tolerance.

\section{Introduction}

Salt stress in the soil or water is the major factor especially in arid and semi-arid regions which greatly influence plant growth and yield. Soil sodicity tolerance is the degree to which a crop can produce satisfactory yield on sodic soil. Salt affects the germination and growth of vegetables by decreasing the availability of water and nutrients. Excessive salt concentrations tend to make the soil moisture less available to plant roots and result in stunted growth of plant. The effects of sodium on crop growth are complicated.

Excessive proportion of sodium in soil frequently restrict plant growth, because unfavourable physical conditions and salt injury becomes more severe as salinity increases (Bernstein, 1959). The use of physiological parameters should simplify the genetics and plant breeding procedure and 
traits associated with tolerance should be identified for successful breeding of salt tolerance cultivar (Blum, 1989). Mithipagal (Momordica charantia var. muricata) is one of the most important cucurbitaceous vegetables cultivated as a wild and landraces in India. Mithipagal is an important vegetable crop grown for its fleshy fruits in tropical and subtropical regions.

Regarding development of genotypes that are sodicity tolerant through breeding approaches, till now very limited attempt has been made in this crop for studying the inheritance pattern of sodicity tolerance. Considering this fact, it is essential to carry out an investigation on genetics of high yield and sodicity tolerance in this crop, by utilizing the landraces available in our country.

Antioxidant enzymes such as catalase (CAT) and peroxidase (POX) are some of the main mechanisms that perform important function in the elimination and neutralization of reactive oxygen species produced under salt stress (Seckin et al., 2010). Catalase is an important cellular antioxidant enzyme that act as defense against salt- induced photorespiration in peroxisomes of leaves (Van Breusegem et al., 2001).

Peroxidase activity may also play a role in the oxidation of phenolic metabolites in roots under stress conditions. Peroxidase activity in cooperation with catalase activity removed excess $\mathrm{H}_{2} \mathrm{O}_{2}$ in the cell and the activity of these enzymes mainly depends on the stress intensity (Sharma et al., 2012).

Increased levels of endogenous proline accumulation in plants is correlated with enhanced salt tolerance (Boscaiu et al., 2012; Sripinyowanich et al., 2013) and induce oxidative stress tolerance by modulating the activities of antioxidant enzymes (Saeedipour, 2013).
Proline acts as a free radical scavenger and may be more important in overcoming stress than in acting as a simple osmolyte (Reddy et al., 2004). There is increasing evidence that salt stress has a significant effect on physiological and biochemical attributes of plants. Better understanding of physiological and biochemical characteristics of plants is vital for improving sodicity tolerance.

To clarify the physiological and biochemical responses of salt-sensitive and salt-tolerant mithipagal genotypes, we investigated the chlorophyll content, proline content and activity of antioxidant enzymes in mithipagal genotypes exposed to sodic soil, which can be used as index for in vitro salt tolerance in mithipagal.

\section{Materials and Methods}

\section{Plant materials and experimental design}

The study was conducted at Horticultural College and Research Institute for Women, Trichy during Kharif season of 2017. Totally thirty two genotypes were collected from different parts of Tamil Nadu were used for this study.

The genotypes are MCM-1 from Allampati, Viruthunagar district, MCM-2 from Karamani kuppam, cuddalore district, MCM-3 from Pudhupatti, Madurai district, MCM-4 from Tamilpaddy, Viruthunagar district, MCM-5 from Rajapalayam, Virudhunagar district, MCM-6 from Pattukottai, MCM-7 from Sathur, Madurai district, MCM-8 from Oddanchatram, Dindigul district, MCM-9 from Tirunelveli, MCM-10 from Aladipatti, Viruthunagar district, MCM-11 from Mannarkudi, Tanjavur district, MCM-12 from Varachur, Madurai district, MCM-13 from Cuddalore, MCM-14 from Suryanarayanamangalam, Tanjavur district, MCM-15 from Kovilpatti, Viruthunagar 
district, MCM-16 from Perundhurai, MCM17 from Amathur, Viruthunagar district, MCM-18 from Kuthallam, Nagapatinam district, MCM-19 from Naduvakurichi, Tuticorin district, MCM-20 from Sathirakootaikanmai, Tuticorin district, MCM-21 from Aruppukottai, Viruthunagar district, MCM-22 from Puthiyamputhur, Tuticorin district, MCM-23 from Vilathikulam, Viruthunagar district, MCM-24 from Chithamparam, Nagapatinam district, MCM-25 from Melapatti, Viruthunagar district, MCM-26 from Narasingam, Madurai district, MCM-27 from Pandavurmangalam, Tuticorin district, MCM-28 from Alanganallur, Madurai district, MCM-29 from Thirumangalam, Madurai district, MCM-30 from Kilavipatti, Tuticorin district. The experiment was laid in Randomized Block Design with three replications. The experimental was laid in sodic soil, having sandy loam texture, with a $\mathrm{pH}$ of 9.00 , EC $0.94 \mathrm{dSm}-1$ and ESP 21.76 per cent. Pits of $60 \mathrm{~cm}$ diameter and $30 \mathrm{~cm}$ depth were taken at a spacing of $2 \times 1.5 \mathrm{~m}$. Five seeds were sown in each pit. The plants were thinned to one seedling per pit after germination. 20 tonnes of FYM / ha along with recommended dose of basal fertilizer $(6: 12: 12 \mathrm{~g}$ of NPK/plant) were applied. The cultural operations and plant protection measures were followed as per the package of practices recommended by TNAU.

\section{Assay of chlorophyll content}

Chlorophyll content was measured according to Porra et al., (1989). An aliquot of fresh leaf $(0.5 \mathrm{~g})$ was suspended in $10 \mathrm{~mL}$ of $80 \%$ acetone, mixed well and kept at room temperature in the dark for 7 days. The supernatant was collected after centrifugation at $5000 \mathrm{rpm}$ for $15 \mathrm{~min}$. The sample absorbance was recorded at 645 and $663 \mathrm{~nm}$ using a spectrophotometer.

\section{Assay of proline content}

Proline content was measured according to Bates et al., (1973). An aliquot of fresh leaf $(0.5 \mathrm{~g})$ was homogenized in $10 \mathrm{~mL}$ of $3 \%$ sulfosalicylic acid and the homogenate was centrifuged at $5000 \mathrm{rpm}$ for $15 \mathrm{~min}$. A total of $2 \mathrm{~mL}$ supernatant was incubated with $2 \mathrm{~mL}$ acid ninhydrin (1.25 g ninhydrin dissolved in $30 \mathrm{~mL}$ glacial acetic acid and $20 \mathrm{~mL}$ of 6 $\mathrm{mol} / \mathrm{L}$ phosphoric acid) and $2 \mathrm{~mL}$ glacial acetic acid for $1 \mathrm{~h}$ at $100{ }^{\circ} \mathrm{C}$, and then quickly cooled in an ice bath. The coloured reaction mixture was extracted with $4 \mathrm{~mL}$ toluene, and the absorbance was recorded at $520 \mathrm{~nm}$.

\section{Assay of peroxidase activity (POD)}

POD activity was determined by the method of Chander (1990). The assay mixture $(3 \mathrm{ml})$ contained $50 \mathrm{mM}$ potassium phosphate buffer $(\mathrm{pH} 7.0), 0.2 \mathrm{~mL}$ of O-phenylenediamine and $30 \mu 1$ of leaf enzyme extract. The reaction was initiated by the addition of hydrogen peroxide $\left(\mathrm{H}_{2} \mathrm{O}_{2}\right)$. The peroxidase activity was estimated by measuring the $\mathrm{H}_{2} \mathrm{O}_{2}$ dependent oxidation of O-phenylenediamine at $450 \mathrm{~nm}$ and

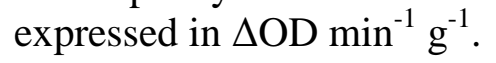

\section{Assay of catalase activity (CAT)}

CAT activity was determined by the procedure of Masia (1998). The assay mixture $(3.0 \mathrm{~mL})$ contained $50 \mathrm{mM}$ potassium phosphate buffer $(\mathrm{pH}$ 7.0), $0.3 \mathrm{~mL}$ of hydrogen peroxide $\left(\mathrm{H}_{2} \mathrm{O}_{2}\right)$ and $100 \mu \mathrm{L}$ of the leaf enzyme extract. The reduction in $\mathrm{H}_{2} \mathrm{O}_{2}$ by the enzyme extract was estimated by reading the reduction of absorbance $240 \mathrm{~nm}$ and expressed in $\mu \mathrm{g}$ of $\mathrm{H}_{2} \mathrm{O}_{2} \mathrm{~g}^{-1} \mathrm{~min}^{-1}$.

\section{Statistical analysis}

Data were subjected to Analysis of Variance (ANOVA) using AGRES statistical package. 


\section{Results and Discussion}

The physiological analysis exhibited a wide range of variation among the mithipagal genotypes. Highly significant variations among the different genotypes in relation to chlorophyll a, chlorophyll b and total chlorophyll were recorded.

Increasing of chlorophyll pigment of the plant for increased biomass production was obtained and was in accordance with the findings of Sujatha (2001). Among the genotypes, MCM-19 recorded the maximum chlorophyll a of $2.207 \mathrm{mg} / \mathrm{g}$ followed by MCM-221 (1.943 mg/g) and MCM-21 (1.641mg/g).

While MCM-8 registered the least chlorophyll a of $1.224 \mathrm{mg} / \mathrm{g}$. The genotype MCM-19 recorded the highest Chlorophyll b content of $0.806 \mathrm{mg} / \mathrm{g}$, followed by MCM-24 and MCM-23 of 0.633 and $0.626 \mathrm{mg} / \mathrm{g}$ respectively.

The genotype MCM-3 recorded the least chlorophyll b of $0.425 \mathrm{mg} / \mathrm{g}$, which was on par with MCM-8 (0.425 mg/g), MCM-6 $(0.447 \mathrm{mg} / \mathrm{g}), \mathrm{MCM}-7 \quad(0.444 \mathrm{mg} / \mathrm{g})$ and MCM-16 (0.441 mg/g). Among the thirty genotypes, MCM-19 registered the highest total Chlorophyll of $2.893 \mathrm{mg} / \mathrm{g}$, followed by MCM-22 and MCM-21 of 2.553 and 2.256 $\mathrm{mg} / \mathrm{g}$, respectively.

The genotype MCM-8 recorded the least total chlorophyll of $1.651 \mathrm{mg} / \mathrm{g}$, which was on par with MCM-3 (1.698 mg/g), MCM-7 (1.697 $\mathrm{mg} / \mathrm{g}$ ) and MCM-16 (1.696 mg/g) (Table 1). Similar findings regarding chlorophyll content have been reported in cucumber Jagesh (2007). The catalase activity in the leaves of mithipagal genotypes was found statistically significant. The maximum catalase activity was obtained in MCM-19 (8.61 $\mu \mathrm{g}$ of $\mathrm{H}_{2} \mathrm{O}_{2} \mathrm{~g}^{-1} \min ^{-1}$ ), which was on par with MCM-22 (8.51 $\mu \mathrm{g}$ of $\mathrm{H}_{2} \mathrm{O}_{2} \mathrm{~g}^{-1} \mathrm{~min}^{-1}$ ). The minimum catalase activity was recorded in MCM-8 (4.2.14 $\mu \mathrm{g}$ of $\mathrm{H}_{2} \mathrm{O}_{2} \mathrm{~g}^{-1} \mathrm{~min}^{-1}$ ), which was on par with MCM-7 (4.51 $\mu \mathrm{g}$ of $\mathrm{H}_{2} \mathrm{O}_{2} \mathrm{~g}^{-1} \mathrm{~min}^{-1}$ ) and MCM-16 (4.54 $\mu \mathrm{g}$ of $\mathrm{H}_{2} \mathrm{O}_{2} \mathrm{~g}^{-1} \mathrm{~min}^{-1}$ ). Similar findings regarding the increased catalase activity have been reported in pumpkin seedlings under salt stress (Sevengor et al., 2011) and in melon (Dantas et al., 2015; Keling et al., 2013) showing the importance of this enzyme in the defense mechanism against oxidative stress under salt stress.

Activity of peroxidase in mithipagal genotypes were significantly affected in response to sodicity stress. The maximum peroxidase activity was obtained in MCM-19 (0.082 $\triangle$ OD $\mathrm{min}^{-1} \mathrm{~g}^{-1}$ ) followed by MCM-21 (0.080 $\Delta$ OD $\left.\min ^{-1} \mathrm{~g}^{-1}\right)$, whereas lowest activity was found in MCM-8 (0.035 $\Delta$ OD min $\left.{ }^{-1} \mathrm{~g}^{-1}\right)$. The mean value for peroxidase activity was (0.055 $\Delta$ OD $\min ^{-1} \mathrm{~g}^{-1}$ ) (Table 2). Similar findings regarding the significant increase in peroxidase activity have been reported in squash (Harter et al., 2014).

Proline content accumulation is regarded as index of tolerance mechanism. The proline content in the salt-tolerant genotypes increased, while proline content in the saltsensitive genotypes decreased significantly. Among the thirty genotypes, maximum proline content was estimated in MCM-19 $\left(650.42 \mu \mathrm{g} \mathrm{g}^{1}\right)$ followed by MCM-22 (640 $\mu \mathrm{g}$ $\left.\mathrm{g}^{-}{ }^{1}\right)$ and MCM-25 (626.51 $\left.\mu \mathrm{g} \mathrm{g}_{-}{ }^{1}\right)$, while minimum proline content was recorded in MCM-8 (235 $\left.\mathrm{g} \mathrm{g}_{-}{ }^{1}\right)$ (Table 2).

In cucumber, Botia et al., (2005), Shi Qing et al., (2006) and Jagesh (2007) reported similar trends of increase in proline content as the salt concentration increased. The higher osmotic adjustment inside the cell may be the reason for increased proline content level in salt stress condition. 
Table.1 Effect of soil sodicity on chlorophyll 'a', chlorophyll 'b' and total chlorophyll content $(\mathrm{mg} / \mathrm{g}$ of $\mathrm{FW})$ in different mithipagal genotypes

\begin{tabular}{|l|c|c|c|}
\hline \multicolumn{1}{|c|}{ Genotypes } & $\begin{array}{c}\text { Chlorophyll 'a' } \\
\text { (mg/g) }\end{array}$ & $\begin{array}{c}\text { Chlorophyll 'b' } \\
\text { (mg/g) }\end{array}$ & $\begin{array}{c}\text { Total Chlorophyll } \\
\text { (mg/g) }\end{array}$ \\
\hline MCM-1 & 1.469 & 0.549 & 2.001 \\
\hline MCM-2 & 1.423 & 0.473 & 1.896 \\
\hline MCM-3 & 1.273 & 0.425 & 1.698 \\
\hline MCM-4 & 1.441 & 0.508 & 1.949 \\
\hline MCM-5 & 1.376 & 0.478 & 1.854 \\
\hline MCM-6 & 1.355 & 0.447 & 1.797 \\
\hline MCM-7 & 1.253 & 0.444 & 1.697 \\
\hline MCM-8 & 1.224 & 0.427 & 1.651 \\
\hline MCM-9 & 1.599 & 0.605 & 2.213 \\
\hline MCM-10 & 1.593 & 0.599 & 2.192 \\
\hline MCM-11 & 1.582 & 0.534 & 2.116 \\
\hline MCM-12 & 1.334 & 0.463 & 1.797 \\
\hline MCM-13 & 1.301 & 0.473 & 1.774 \\
\hline MCM-14 & 1.372 & 0.479 & 1.851 \\
\hline MCM-15 & 1.321 & 0.484 & 1.788 \\
\hline MCM-16 & 1.255 & 0.441 & 1.696 \\
\hline MCM-17 & 1.391 & 0.487 & 1.879 \\
\hline MCM-18 & 1.447 & 0.497 & 1.944 \\
\hline MCM-19 & 2.207 & 0.806 & 2.893 \\
\hline MCM-20 & 1.345 & 0.507 & 1.866 \\
\hline MCM-21 & 1.641 & 0.615 & 2.256 \\
\hline MCM-22 & 1.943 & 0.609 & 2.553 \\
\hline MCM-23 & 1.536 & 0.626 & 2.161 \\
\hline MCM-24 & 1.526 & 0.633 & 2.159 \\
\hline MCM-25 & 1.621 & 0.597 & 2.218 \\
\hline MCM-26 & 1.442 & 0.463 & 1.905 \\
\hline MCM-27 & 1.531 & 0.535 & 2.066 \\
\hline MCM-28 & 1.429 & 0.496 & 1.925 \\
\hline MCM-29 & 1.517 & 0.585 & 2.102 \\
\hline MCM-30 & 1.474 & 0.520 & 1.994 \\
\hline Mean & $\mathbf{1 . 4 7 5}$ & $\mathbf{0 . 5 2 8}$ & $\mathbf{1 . 9 9 7}$ \\
\hline SEd & $\mathbf{0 . 0 1 1}$ & $\mathbf{0 . 0 1 2}$ & $\mathbf{0 . 0 4 3}$ \\
\hline CD(0.05) & $\mathbf{0 . 0 2 2}$ & $\mathbf{0 . 0 3 6}$ & \\
\hline & & & \\
\hline
\end{tabular}


Table.2 Effect of soil sodicity on catalase activity $\left(\mu \mathrm{g}\right.$ of $\mathrm{H}_{2} \mathrm{O}_{2} \mathrm{~g}^{-1} \mathrm{~min}^{-1}$ ), peroxidase activity $\left(\triangle \mathrm{OD} \mathrm{min}^{-1} \mathrm{~g}^{-1}\right)$ and proline content $\left(\mu \mathrm{g} \mathrm{g}^{-1}\right)$ in different mithipagal genotypes

\begin{tabular}{|c|c|c|c|}
\hline Genotypes & $\begin{array}{l}\text { Catalase activity ( } \mu \mathrm{g} \text { of } \\
\quad \mathrm{H}_{2} \mathrm{O}_{2} \mathrm{~g}^{-1} \mathrm{~min}^{-1} \text { ) }\end{array}$ & $\begin{array}{l}\text { Peroxidase activity } \\
\left(\Delta \text { OD } \operatorname{~in}^{-1} \mathrm{~g}^{-1}\right)\end{array}$ & $\begin{array}{l}\text { Proline content } \\
\left(\mu g g^{1}\right)\end{array}$ \\
\hline MCM-1 & 6.34 & 0.057 & 433.33 \\
\hline MCM-2 & 5.83 & 0.048 & 341.67 \\
\hline MCM-3 & 4.77 & 0.037 & 263.33 \\
\hline MCM-4 & 6.16 & 0.054 & 414.33 \\
\hline MCM-5 & 5.55 & 0.043 & 311.67 \\
\hline MCM-6 & 5.27 & 0.041 & 281.67 \\
\hline MCM-7 & 4.51 & 0.038 & 258.33 \\
\hline MCM-8 & 4.24 & 0.035 & 235.00 \\
\hline MCM-9 & 7.32 & 0.074 & 525.00 \\
\hline MCM-10 & 7.29 & 0.072 & 513.16 \\
\hline MCM-11 & 6.49 & 0.058 & 448.33 \\
\hline MCM-12 & 5.37 & 0.046 & 301.33 \\
\hline MCM-13 & 4.61 & 0.039 & 261.67 \\
\hline MCM-14 & 5.60 & 0.045 & 331.67 \\
\hline MCM-15 & 5.04 & 0.040 & 271.67 \\
\hline MCM-16 & 4.54 & 0.037 & 253.33 \\
\hline MCM-17 & 5.44 & 0.042 & 306.67 \\
\hline MCM-18 & 5.95 & 0.052 & 391.67 \\
\hline MCM-19 & 8.61 & 0.082 & 650.42 \\
\hline MCM-20 & 5.72 & 0.047 & 316.67 \\
\hline MCM-21 & 8.26 & 0.080 & 640.00 \\
\hline MCM-22 & 8.51 & 0.078 & 600.18 \\
\hline MCM-23 & 7.26 & 0.070 & 511.67 \\
\hline MCM-24 & 6.55 & 0.064 & 463.33 \\
\hline MCM-25 & 7.80 & 0.073 & 626.51 \\
\hline MCM-26 & 5.58 & 0.049 & 351.63 \\
\hline MCM-27 & 6.34 & 0.061 & 443.33 \\
\hline MCM-28 & 6.13 & 0.052 & 410.00 \\
\hline MCM-29 & 6.80 & 0.069 & 466.67 \\
\hline MCM-30 & 6.35 & 0.053 & 415.00 \\
\hline Mean & 6.140 & 0.055 & 401.31 \\
\hline SEd & 0.161 & 0.001 & 5.072 \\
\hline $\operatorname{CD}(0.05)$ & 0.322 & 0.001 & 10.15 \\
\hline
\end{tabular}


It is clear that increased antioxidant enzyme (CAT and POX) activity, chlorophyll content and proline content in mithipagal genotypes could be some of the physiological and biochemical mechanisms underlying sodicity tolerance in mithipagal genotypes. On the basis of biochemical assays, MCM-19 (Naduvakurichi local) showed a higher tolerance to sodicity followed by MCM-22 (Puthiyamputhur local) and MCM21(Arupukottai local). These findings may serve as an in vitro selection criteria for salt tolerance in mithipagal. These genotypes can be utilized as source for hybridization programme for further crop improvement.

\section{References}

Bates, L. S., Waldren, R. P. and Teare, I. D. 1973. Rapid determination of free proline for water-stress studies. Plant Soil, 39(1): 205-207.

Bernstein, L. 1959. Salt tolerance of vegetable crops in the West. Agricultural Research Service, USDA. Agriculture Information Bulletin No. 205.

Blum, A. 1989. 11 Breeding methods for drought resistance. Plants under stress: biochemistry, physiology, and ecology and their application to plant improvement, 39: 197.

Boscaiu, M., Lull, C., Llinares, J., Vicente, O. and Boria, H. 2012. Proline as a biochemical marker in relation to the ecology of two halophytic Juncus species. J Plant Ecol, 6(2): 177-186

Botia, P., Navarro, J., Cerdá, A. and Martinez, V. 2005. Yield and fruit quality of two melon cultivars irrigated with saline water at different stages of development. European Journal of Agronomy, 23(3): 243-253.

Dantas, B. F., Da Silva, R. D. C. B., Ribeiro, R. C. and Aragao, C. A. 2015. Respiration and antioxidant enzymes activity in watermelon seeds and seedlings subjected to salt and temperature stresses. American Journal of Experimental Agriculture, 7(2): 70.

Flowers, T. and Yeo, A. 1995. Breeding for salinity resistance in crop plants: where next? Functional Plant Biology, 22(6): 875-884.

Harter, L. D. S. H., Harter, F. S., Deuner, C., Meneghello, G. E. and Villela, F. A. 2014. Salinidade e desempenho fisiológico de sementes e plântulas de mogango. Horticultura Brasileira, 32 (01).

Jagesh, K. 2007. Genetic studies on yield and soil Salinity tolerance in cucumber (Cucumis sativus L.). Ph.d (Hort.), Indian Agricultural Research Institute, New Delhi.

Keling, H., Zhang, L., Jitao, W., and Yang, Y. 2013. Influence of selenium on growth, lipid peroxidation and antioxidative enzyme activity in melon (Cucumis melo L.) seedlings under salt stress. Acta Societatis Botanicorum Poloniae, 82(3):193.

Reddy, A. R., Chaitanya, K. V. and Vivekanandan, M. 2004. Droughtinduced responses of photosynthesis and antioxidant metabolism in higher plants. Journal of Plant Physiology 161: 1189-1202.

Saeedipour, S. 2013. Relationship of grain yield, ABA and proline accumulation in tolerant and sensitive wheat cultivars as affected by water stress. Proc Natl Acad Sci USA, 83(3): 311-315.

Seckin, B., Turkan, I., Sekmen, A. H. and Ozfidan, C. 2010. The role of antioxidant defense systems at differential salt tolerance of Hordeum marinum Huds (sea barleygrass) and Hordeum vulgare L. (cultivated barley). Environmental and Experimental Botany, 69(1), 76-85.

Sevengor, S., Yasar, F., Kusvuran, S. and 
Ellialtioglu, S. 2011. The effect of salt stress on growth, chlorophyll content, lipid peroxidation and antioxidative enzymes of pumpkin seedling. African Journal of Agricultural Research, 6(21): 4920-4924.

Sharma, P., Jha, A. B., Dubey, R. S. and Pessarakli, M. 2012. Reactive oxygen species, oxidative damage, and antioxidative defense mechanism in plants under stressful conditions. Journal of botany, 2:306-312

Sripinyowanich, S., Klomsakul, P., Boonburapong, B., Bangyeekhun, T., Asami, T., Gu, H.Y., Buaboocha, T. and Chadchawan, S. 2013. Exogenous
ABA induces salt tolerance in indica rice (Oryza sativa L.): The role of OsP5CS1 and OsP5CR gene expression during salt stress tolerance in indica rice (Oryza sativa L.). Environ Exp Bot, 86: 94-105.

Sujatha, K. B. 2001. Effect of foliar spray of chemical and bioregulators on growth and yield of greengram. M.Sc.(Ag.), Tamil Nadu Agricultural University, Coimbatore.

Van Breusegem, F., Vranova, E., Dat, J. F. and Inze, D. 2001. The role of active oxygen species in plant signal transduction. Plant Science, 161(3): 405-414.

\section{How to cite this article:}

Priyadharshini, S., K. Kumanan and Sabir Ahamed, A. 2020. Physiological Responses of Mithipagal Genotypes (Momordica charantia var. muricata L.) under Sodic Condition. Int.J.Curr.Microbiol.App.Sci. 9(06): 3709-3716. doi: https://doi.org/10.20546/ijcmas.2020.906.438 